\title{
A profile of corneal ulcers - 2 years study from rural hospital, Haryana.
}

\author{
Dr Kanishtha Sharma, Dr Sonia Mehta, Dr Varsha A Singh, Dr Shivya Jamwal, \\ Dr Tanya Sharma, Dr Prafulla Kumar Manjhi. \\ 3rd Year Resident P.G., Department of Microbiology, MMIMSR, Mullana, Ambala (Haryana) \\ Associate Professor, Department of Microbiology, MMIMSR, Mullana, Ambala (Haryana), Professor and \\ Head, Department of Microbiology, MMIMSR, Mullana, Ambala (Haryana), $3^{\text {rd }}$ Year Resident P.G., \\ Department of Microbiology, MMIMSR, Mullana, Ambala (Haryana), $3^{\text {rd }}$ Year Resident P.G., Department of \\ Microbiology, MMIMSR, Mullana, Ambala (Haryana), Professor and Head, Department of Ophthalmology, \\ MMIMSR, Mullana, Ambala (Haryana)
}

\begin{abstract}
Corneal ulceration is a leading cause of ocular morbidity and blindness worldwide. The present study was carried out by the Department of Microbiology \& Ophthalmology, MMIMSR, on 60 corneal scraping samples from clinically suggested cases of corneal ulcers. Corneal scrapings were collected and subjected to microscopy and culture. Out of the 60 patients suspected of having bacterial and fungal keratitis, $43.3 \%$ were found to be culture positive. Rate of detection of bacterial and fungal and mixed growth was $30.76 \%, 61.53 \%$ and $7.69 \%$ respectively. Ocular trauma (68.3\%) was the most common predisposing factor followed by Topical steroids (14.6\%) and Diabetes mellitus (7.31\%). Sugarcane leaf accounted for (37.5\%) cases followed by paddy leaf, wood chip and iron piece which accounted for (12.5\%) cases each. Among the clinical features, redness $81.25 \%)$, blurred/diminished vision (81.25\%), pain (68.7\%), irregular feathery margins (75\%) was most commonly seen in fungal keratitis while Pain (75\%), redness (87.5\%), lacrimation (62.5\%), hypopyon (37.5\%) was most commonly seen in bacterial keratitis. Accurate diagnostic tests not only play a key role in patient management but also reduce the risk of the patient developing long-term complications. The definitive diagnosis of ulcers caused by multiple organisms can only be arrived at by microbiological evaluation.
\end{abstract}

Keywords: Corneal ulcer, Clinical presentations, Microbiological diagnosis, Ocular morbidity.

\section{Introduction}

Corneal ulcer is a major cause of blindness throughout the world. India being an agricultural land, superficial corneal trauma in farming which frequently leads to rapidly progressing corneal ulceration and visual loss is very common. (Srinivasan et al $1997^{1}$, Basak et al $2005^{2}$, Gopinathan et al $2009^{3}$ ). Bacteria and fungi frequently cause suppurative keratitis. Clinical features aid the ophthalmologists in clinical diagnosis and starting of empirical treatment of patients with infective keratitis but often the clinical features donot correlate to the classical textbook description. . Most of the studies about microbial keratitis have primarly evaluated epidemiological features, causative agents and antibiotic sensitivity patterns (Geethakumari et al $2011^{4}$, Tewari et al $2012^{5}$, Balagurunathan et al $2012^{6}$, Kunwar et al $2013^{7}$ ). Haryana being the agricultural hub of the country with hot and humid climate, ocular trauma due to vegetative matter i.e., sugarcane leaf and paddy leaf is very common, this study along with the identification of causative organisms and predisposing factors also studied the clinical profile of corneal ulcers.

\section{Material And Methods}

A study was carried out by the Department of Microbiology \& Ophthalmology, MMIMSR, Mullana on 60 patients attending Ophthalmology OPD and IPD in clinically suggested cases of corneal ulceration. A detailed clinical history of patient was taken. Using slit lamp a thorough examination of the affected eye was done by the ophthalmologist and the ulcer details were noted. After a detailed clinical examination of the eye, the eye was cleaned with sterile normal saline to remove all necrotic exudates. The eye was then locally anaesthetized by using 2-3 drops of $4 \%$ lignocaine hydroxide without preservative. Scrapings of the corneal ulcer were collected using a sterile Bard Parker blade no.15 or Kimura's Scapula. The base of the ulcer as well as the edges was thoroughly scrapped to obtain as much material as possible. Direct microscopic examination of the corneal scraping was performed with $10 \%$ potassium hydroxide $(\mathrm{KOH})$ wet mount and Calcofluor white staining. The scrapings were inoculated on Blood agar for culture of bacterial isolates and incubated at $37 \mathrm{C}$ for 18-24 hrs and identified on the basis of microscopic morphology, staining characteristics and confirmed by putting up the battery of biochemical reactions. For fungal culture the scraping were directly inoculated on two slants of Sabourand's dextrose agar (With gentamycin and chloramphenicol) incubated at $25^{\circ} \mathrm{C}$ and the other at 
A profile of corneal ulcers - 2 years study from rural hospital, Haryana.

$37^{\circ} \mathrm{C}$. Identification was made based on colony characters, rate of growth and microscopic examination by lactophenol cotton blue stain wet mount.

\section{Results}

In the present study out of 60 cases, the rate of detection of culture positive cases was (43.3\%) while $(56.6 \%)$ showed no growth.

\begin{tabular}{|c|c|c|}
\hline $\begin{array}{l}\text { Total no. of clinically suscepted } \\
\text { Bacterial and Fungal keratitis cases }\end{array}$ & $\begin{array}{l}\text { Total no. of culture } \\
\text { positive cases }\end{array}$ & No growth \\
\hline 60 & $26(43.3 \%)$ & $34(56.6 \%)$ \\
\hline
\end{tabular}

Table 1: Rate of Bacterial and Fungal agents in clinically suspected cases of corneal ulcer

The positivity rate of fungal isolates was $61.53 \%, 30.76 \%$ for bacterial isolates whereas $7.69 \%$ showed mixed (bacterial and fungal) isolates.

\begin{tabular}{|c|c|c|c|}
\hline No.of isolates & Pure Bacterial isolates & Pure Fungus isolates & $\begin{array}{l}\text { Mixed } \\
\text { isolates }\end{array}$ \\
\hline 26 & $8(30.76 \%)$ & $16(61.53 \%)$ & $2(7.69 \%)$ \\
\hline
\end{tabular}

Table 2: Rate of detection of Bacterial and Fungal isolates in corneal ulcer

In predisposing factor the bacterial and fungal keratitis was predominantly associated with ocular trauma (61.53\%), followed by topical steroids (19.23\%) and Diabetes mellitus (7.69\%).

\begin{tabular}{|l|c|l|}
\hline Predisposing Factor & $\begin{array}{l}\text { Total } \\
\text { Number } \\
\text { of cases }\end{array}$ & $\begin{array}{l}\text { Bacterial and } \\
\text { fungal } \\
\text { keratitis }\end{array}$ \\
\hline Ocular trauma & 28 & $16(61.53 \%)$ \\
\hline Diabetes Mellitus & 3 & $2(7.69 \%)$ \\
\hline $\begin{array}{l}\text { Acute and Chronic } \\
\text { Conjuctivitis }\end{array}$ & 2 & $1(3.8 \%)$ \\
\hline Contact Lens Wear & 2 & $2(7.69 \%)$ \\
\hline Topical Steroids & 6 & $5(19.23 \%)$ \\
\hline $\begin{array}{l}\text { No predisposing } \\
\text { factors }\end{array}$ & 19 & $0(0 \%)$ \\
\hline Total & 60 & $26(43.3 \%)$ \\
\hline
\end{tabular}

Table 3: Frequency of predisposing factors in bacterial and fungal keratitis

Sugarcane leaf accounted for 6 (37.5\%) cases followed by paddy leaf, wood chip and iron piece which accounted for $2(12.5 \%)$ cases.

\begin{tabular}{|l|l|l|}
\hline \multirow{5}{*}{ Vegetative origin } & $\begin{array}{l}\text { Nature of } \\
\text { trauma }\end{array}$ & No of cases \\
\hline \multirow{5}{*}{ Foreign body } & $\begin{array}{l}\text { Sugarcane } \\
\text { leaf }\end{array}$ & $6(37.5 \%)$ \\
\cline { 2 - 3 } & Paddy leaf & $2(12.5 \%)$ \\
\cline { 2 - 3 } & Grass stick & $2(12.5 \%)$ \\
\cline { 2 - 3 } & Thorn prick & $2(12.5 \%)$ \\
\hline & Wood chip & $2(12.5 \%)$ \\
\cline { 2 - 3 } & Iron piece & $1(6.25 \%)$ \\
\cline { 2 - 3 } & Stone & $1(6.25 \%)$ \\
\hline & Total & 16 \\
\hline
\end{tabular}

TABLE 4: Correlation of type of trauma and microbial infection

It depicts that among the clinical features redness $(81.25 \%)$, blurred/diminished vision $(81.25 \%)$, pain (68.7\%), irregular feathery margins $(75 \%)$ was most commonly seen in fungal keratitis. Pain (75\%), redness (87.5\%), lacrimation (62.5\%), hypopyon (37.5\%) was most commonly seen in bacterial keratitis. 
A profile of corneal ulcers - 2 years study from rural hospital, Haryana.

\begin{tabular}{|l|l|l|}
\hline \multicolumn{1}{|c|}{ Clinical Features } & $\begin{array}{l}\text { Fungal keratitis } \\
\text { N=16 }\end{array}$ & \multicolumn{1}{c|}{$\begin{array}{c}\text { Bacterial keratitis } \\
\mathbf{N = 8}\end{array}$} \\
\hline SYMPTOMS & & \\
\hline Redness & $13 / 16(81.2 \%)$ & $7 / 8(87.5 \%)$ \\
\hline Pain & $11 / 16(68.7 \%)$ & $6 / 8(75 \%)$ \\
\hline Lacrimation & $09 / 16(56.3 \%)$ & $5 / 8(62.5 \%)$ \\
\hline Photophobia & $07 / 16(43.7 \%)$ & $3 / 8(37.5 \%)$ \\
\hline Blurred/Diminished vision & $13 / 16(81.2 \%)$ & $6 / 8(75 \%)$ \\
\hline SIGNS & & \\
\hline Lid oedema & $05 / 16(31.2 \%)$ & $5 / 8(62.5 \%)$ \\
\hline Hypopyon & $03 / 16(18.7 \%)$ & $3 / 8(37.5 \%)$ \\
\hline Conjunctival congestion & $05 / 16(31.2 \%)$ & $3 / 8(37.5 \%)$ \\
\hline Irregular feathery margins & $12 / 16(75 \%)$ & $4 / 8(50 \%)$ \\
\hline
\end{tabular}

Table 5: Distribution of clinical features in bacterial and fungal keratitis

\section{Discussion}

In the present study the rate of detection of bacterial and fungal and mixed growth was $30.76 \%$, $61.53 \%$ and $7.69 \%$ respectively which is comparable to comparable with Shrinivasan et $\mathrm{al}^{1}$ and Basak et $\mathrm{al}^{2}$. Higher incidence of fungal keratitis $(61.53 \%)$ was seen. Bharathi et $\mathrm{al}^{8}(34.4 \%)$ and Ghana study by leek et $\mathrm{al}^{9}$ (37.6\%) has shown lesser incidence whereas Geethakumari et $\mathrm{al}^{4}(69.78 \%)$ has reported a much higher incidence of fungal keratitis. It may be due to hot and humid climate of this region. Another reason may be because this study was conducted at a tertiary care centre so fungal ulcers reported are more due to their prolonged course and poor response to available topical medications. Ocular trauma $68.3 \%$ was the most common predisposing factor followed by topical steroids (19.23\%) and diabetes mellitus (7.69\%). Assudani HJ et $\mathrm{al}^{10}$ (trauma $44.45 \%$, diabetes mellitus $29.5 \%$, contact lens wearers $14.82 \%$ \& steroid $3.70 \%$ ) and Kumar et $\mathrm{al}^{11}$ where ocular trauma constituted $78.5 \%$ of the cases. This may be because most of the patients in the present study were involved in agriculture occupation where injury to the eye was very common. Another predisposing factor was use to topical steroids (14.6\%). This could to due to the easy availability of the steroid eye drops in our country. Moreover, due to illiteracy, patients keep on using these eye drops continuously for longer periods, many times even without prescription. Trauma due to vegetable origin (75\%), sugarcane leaf and paddy leaf accounted for $50 \%$ and $16.6 \%$ of the cases respectively. This is in accordance to Sanjeev H et al ${ }^{12}(54.54 \%)$ and Katara RS et $\mathrm{al}^{13}(62 \%)$. Injury with sugarcane and paddy leaf predominates as they were the principal agricultural products in this region and majority of the farming community are engaged in these two crops. Sugarcane leaf because of its length can easily injure the eye during harvesting of crop. In the present study, the clinical features redness (81.25\%), blurred/diminished vision (81.25\%), pain (68.7\%), irregular feathery margins (75\%) was most commonly seen in fungal keratitis. Pain $(87.5 \%)$, redness $(87.5 \%)$, lacrimation $(62.5 \%)$, hypopyon $(37.5 \%)$ was most commonly seen in bacterial keratitis. This was comparable with Ibrahim et al ${ }^{14}$ (Red eye - Bacterial $89.22 \%$ fungal $87 \%$, Pain - Bacterial $90.32 \%$ Fungal $87.55 \%$,Photophobia-Bacterial 67.74\% Fungal $86.67 \%$,Poor vision -Bacterial 71.67\% Fungal-93.49\%, Hypopyon (Bacterial 36\% Fungal $16 \%$ ) and Thomas et $\mathrm{al}^{15}$ (Serrated margins- fungal $79 \%$ bacterial $48 \%$, Hypopyon- fungal $48 \%$ bacterial $65 \%$, dry texture- fungal $44 \%$ bacterial $28 \%$ ). Fungal aetiology is mostly presumed with hyphal pattern, serrated margins, raised slough, dry textured slough, and satellite lesions. In contrast, bacterial aetiology is suspected when symptoms are more prominent. It is marked by clinical features i.e.; flat, dry slough, margins well defined, hypopyon, keratic precipitates, flare or cells in the anterior chamber (AC), and deep lesions, but the practical experience in treating cases of fungal keratitis shows that the clinical features do not always correlate with the textbook description. Certain clinical characteristics of corneal ulcers may suggest a specific pathogen, but a reliable diagnosis cannot be made by clinical appearance alone and microbiological investigations should be performed.

\section{Conclusion:}

Suppurative keratitis is an avoidable vision-threatening disease that still represents a considerable proportion of the daily new cases that creates a huge burden on the resources of health services. The clinical presentations of bacterial and fungal corneal ulcers are often overlapping and thus confirmation by microbiological diagnosis is very essential in order to limit the ocular morbidity and prevent complications. 


\section{References:}

[1] Srinivasan M, Gonzales CA, George C, et al. Epidemiology and etiological diagnoses of corneal ulceration in Madurai, South India. Br J Ophthalmol. 1997; 81(2):965-71.

[2] Basak SK, Basak S, Mohanta A, Bhowmick A. Epidemiological and microbiological diagnosis of suppurative keratitis in Gangatic West Bengal, Eastern India. Indian J Ophthalmol.2005; 53(1):17-22.

[3] Gopinathan U, Sharma S, Garg P, Rao GN. Review of epidemiological features, microbial diagnosis and treatment outcome of microbial keratitis: Experience of over a decade. Indian J Ophthalmol. 2009; 57(2): 273-79.

[4] Geethakumari, P.V., Remya, R., Girijadevi, M.S., Reena, A. Bacterial Keratitis and Fungal Keratitis in South Kerala: A Comparative Study. 2011. KJO. 23(1):43-46.

[5] Tewari A, Sood N, Vegad MM, Mehta DC. Epidemiological and microbiological profile of infective keratitis in Ahmedabad. Indian J Ophthalmol. 2012; 60(2):267-72.

[6] Balagurunathan R, Shanthi J, Vanaja priya R.Laboratory diagnosis and prevalence study of corneal infections from a tertiary eye care hospital. Adv. Appl. Sci. Res. 2012; 3(3):1598-1602.

[7] Kunwar M, Adhikari RK, Karki DB. Microbial Flora of Corneal Ulcer and their Drugs Sensitivity. MJSBH. 2013; 12(1):14-17.

[8] Bharathi M.J, Ramakrishnan R, Vasu S, Meenakshi, Palaniappan R. Aetiological diagnosis of microbial keratitis in South India - A study of 1618 cases. Indian J Med Microbiol. 2002; 20(1):19-24.

[9] Leck AK, Thomas PA, Hagan M, Kaliamurthy J, Ackuaku E, John M, et al. Aetiology of suppurative corneal ulcers in Ghana and south India, and epidemiology of fungal keratitis. Br J Ophthalmol. 2002; 86(11):1211-215.

[10] Assudani JH, Pandya JM, Sarvan RR, Sapre AM, Gupta AR, Mehta SJ. Etiological diagnosis of microbial keratitis in a tertiary care hospital in Gujarat, National Journal of Medical Research. 2013; 3(1):60-2.

[11] Kumar A, Pandya, S, Kavathia G, Antala S, Madan M, Javdekar T. Microbial keratitis in Gujarat, Western India: findings from 200 cases. Pan Afr Med J. 2011; 10(1):48-56.

[12] Sanjeev H, Karnaker Vimal K, Pai Vijay, Pai Asha K.B, Rai Rekha, Krishnaprasad M.S.Fungal Profile of infectious keratitis in a tertiary care hospital- our experience. NUJHS. 2012; 2(2):10-14.

[13] Katara RS, Patel ND, Sinha M. A Clinical Microbiological Study of Corneal Ulcer Patients at Western Gujarat, India.Acta Medica Iranica. 2013; 51(6):399-403.

[14] Ibrahim MM, Vanini R, Ibrahim FM, Fioriti LS, Furlan EMR, Rovinzano LMA, De Castro RS, E Faria E Sousa SJ, Rocha EM. Epidemiologic aspects and clinical outcome of fungal keratitis in southeastern Brazil. E Journal Ophthalmol. 2009; 19(3):355-61.

[15] Thomas PA, Leck AK, Myatt M. Characteristic clinical features as an aid to the diagnosis of suppurative keratitis caused by filamentous fungi. Br J Ophthalmol. 2005; 89(2):1554-58. 